\title{
Türkiye'de Sığır Eti Üretimi ve Dış Ticaretinde Son 25 Ylllık Tarımsal Politikaların ve Uygulamaların Değerlendirilmesi
}

Özge Can Niyaz

Çanakkale Onsekiz Mart Üniversitesi, Ziraat Fakültesi, Tarım Ekonomisi Bölümü, Çanakkale/TÜRKiYE

凹: ozgecanniyaz@comu.edu.tr

\begin{abstract}
ÖZET
Gelişmiş toplumların beslenme biçimleri incelendiğinde hayvansal protein tüketiminin gelişmemiş toplumlara göre oldukça fazla olduğu görülmektedir. Yeterli miktarda protein tüketebilmek beslenme anlamında bir gelişmişlik göstergesidir. Ulusların yeterli miktarda protein alımı içeren beslenme düzenlerine sahip olması ise bu alandaki tarımsal politikalar ve bu politikaların uygulamaları ile doğrudan ilişkilidir. Türkiye'de kişi başına hayvansal protein tüketimi gelişmiş ülkelerin oldukça gerisinde kalmaktadır. Bunun temel sebebi ise kırmızı et üretim ve dış ticaret politikalarının doğru belirlenememesi veya uygulanamamasıdır. Kırmızı et üreticisi ve tüketicisi bu aksaklıklardan doğrudan etkilenmektedir. Bu nedenle, bu çalışmanın amacı Türkiye'nin son 25 yıllık döneminde sığır eti üretim ve dış ticaretinde belirlenen ve uygulanan politikaların irdelenmesidir. Çalışmada resmi raporlar ve akademik çalışmalardan alınan veriler derlenmiştir. Sığır eti üretimi yıllar itibari ile incelendiğinde mevcut tüketim düzeyinde yeterli görülmektedir. Fakat Türkiye'de kırmızı et tüketimi gelişmiş ülkelerin gerisindedir. Buna göre daha yüksek bir tüketim düzeyi için mevcut sığır üretiminin de yetersiz kaldığı görülmektedir. Dış ticaret verileri incelendiğinde, 2010 yılında başlayan sığır eti ithalatın uzun vadede tüketici fiyatlarında düşüşün aksine fiyat düzeyinde artışa sebep olduğu görülmüştür. Artan girdi maliyetleri ve ithalat yerli sığır yetiştiricilerinin önünde duran en büyük engellerdir. Buna göre; Türkiye'nin sığır eti ihtiyacının karşılanması yerli üreticiyi destekleyecek politikaların güçlendirilmesi yolu ile yapılmalıdır. Et Balık Kurumu et işleme kapasitesini nüfusun ihtiyacını karşılayacak şekilde genişletmeli ve tekrar piyasa üzerinde aktif rol oynar hale getirilmelidir.
\end{abstract}

\section{Evaluation of Agricultural Policy and Practice of Turkey Beef Meat Production and Foreign Trade in Last 25 Years}

\section{ABSTRACT}

When nutritional forms of developed societies are examined, it is seen that consumption of animal protein is considerably higher than in undeveloped societies. Sufficient protein consumption is a developmental sign in terms of nutrition. The fact that nations have sufficient nutritional supplements for protein intake is directly related to the agricultural policies and practices of these policies. Animal protein consumption per capita in Turkey lags far behind the developed countries. The main reason for this is that red meat production and foreign trade policies can not be correctly determined or implemented. Red meat producers and consumers are directly affected by these disruptions. Therefore, this study aimed to examine beef production and foreign trade policies implemented in Turkey in the last 25-year. In the study, official reports and data from academic studies were compiled. When the beef production is examined by years, current consumption level looks sufficient. But, meat
\end{abstract}

Makale Tarihçesi

Geliş : 20.10.2018

Kabul : 28.12.2018

Anahtar Kelimeler

Ithalat,

Politika,

Siğir Eti,

Üretim,

Türkiye

\section{Derleme Makalesi}

Article History

Received : 20.10.2018

Accepted : 28.12.2018

Keywords
Import,
Policy,
Beef,
Production,
Turkey

Review Article 
consumption in Turkey is lower than that of developed countries. Accordingly, for a higher consumption level, the current cattle production is also insufficient. When the foreign trade data are analyzed, it is seen that the beef import started in 2010 has led to an increase in the price level in contrast to the decline in consumer prices in the long term. Increased input costs and imports are the major obstacles to domestic cattle breeders. According to this; it should be made to meet the needs of Turkey's beef with the way the strengthening of policies to support domestic producers. The Meat Fish Authority should expand its meat processing capacity to meet the needs of the population and to play an active role on the market again.

To cite: Niyaz ÖC 2018. Türkiye'de Sığır Eti Üretimi ve Dış Ticaretinde Son 25 Yıllık Tarımsal Politikaların ve Uygulamaların Değerlendirilmesi. KSÜ Tar Doğa Derg 21(Özel Sayl) : 237-244, DOI : ksutarimdoga.v21i41625.472856

\section{GIRIŞ}

Beslenme; insan hayatının sürdürülebilmesi için zorunlu bir ihtiyaçtır. Sağlıklı ve dengeli beslenme ise tüm insanlar için bir haktır. Buna rağmen dünyada birçok insan yetersiz ve dengesiz beslenme sorunu ile karşı karşıyadır (Anonim, 2013a). Gelişmiş toplumların beslenme düzenlerine bakıldığında, bu toplumlardaki bireylerin yeterli ve dengeli miktarda hayvansal protein tüketebildikleri görülmektedir (Gürer ve Ören, 2013; Niyaz ve İnan, 2016). Toplumu oluşturan bireylerin, hayvansal protein kaynaklarına ulaşabilmeleri için ise ülkelerin tarım politikaları ve bu politikaların uygulamaları oldukça önemlidir. Sağlıklı bir beslenme düzeninde vücudun protein ihtiyacının \% 40-50'sinin hayvansal kökenli gıdalardan gelmesi gerekmektedir. Türkiye'de bu oran \% 29'da kalmaktadır (Gündüz ve ark., 2006; Anonim, 2016). Bu oranın düşük olmasının temel sebebi ulusal düzeyde belirli ve tutarlı bir hayvancılık politikasının olmamasıdır (Dağdemir ve ark., 2003; Turhan ve ark., 2010; Karakuş, 2011).

Türkiye'de kırmızı ete ekonomik erişilebilirliğinin sağlanması oldukça uzun bir süreci kapsayan kronikleşmiş bir sorundur. Son 25 yıllık dönemde uygulanan politikalar ile bu sorun daha da büyümüştür (Lorcu ve Bolat, 2012). Özellikle 2010 yılında kırmızı et ithalatına uygulanan örtülü ambargonun kaldırılması uzun dönemde tüketici fiyatlarını olumsuz etkilemiştir. Tarımda dışa bağımlı ülkelerin uzun vadede oldukça önemli bedeller ödedikleri bilinmektedir. Ithalat seçeneği kısa dönemde kurtarıcı gibi görünse de uzun vadede gıda egemenliği açısından önemli bir tehdit unsurudur (Özkaya, 2017). İthalatın; kısa vadede tüketici fiyatını düşürmesi beklenirken; orta ve uzun vadede üreticilerin yerli üretimden vazgeçmesi sonucunda fiyatı daha da yükseltecektir. Yerli üretimin sona ermesi ise üretici ve tüketici açısından sosyoekonomik pek çok başka soruna yol açacaktır.

Bu konunun amacı Türkiye'de özellikle son 25 yıllık dönemde belirlenen ve uygulanan sı̆̆ır eti üretim ve dış ticaret politikalarının irdelenmesidir. Kırmızı et üretiminin \% 80'den fazlasını sığır eti oluşturmaktadır (Anonim, 2017a). Bu nedenle ürün kapsamına sığır eti alınmıştır. Bu çalışma ikincil verilerden oluşmaktadır. Resmi kurumlardan derlenen istatistiklerin yanı sıra resmi raporlar ve akademik çalışmalardan da yararlanılmıştır.

\section{Türkiye'de Sığır Eti Üretimi ve Tüketimi}

Türkiye'deki sığır eti üretimine ait veriler 1992-2016 yılları arasındaki dönem için incelenmiştir (Çizelge 1). Buna göre 1992 yılında 300 bin ton civarında olan sığır eti üretimi 2016 yılına gelindiğinde dört kattan fazla artarak 1.3 milyon ton civarına ulaşmıştır. 25 yılda gerçekleşen bu artış önemli olmakla birlikte yeterli görülmemektedir. Yine aynı yıllar arasında sığır varlığı incelendiğinde 1992 yılından 2016 yılına kadar sığır varlığında yaklaşık sadece 2 milyon baş hayvan artışı gözlenmektedir. Aynı yıllar arasında ülke nüfusu incelendiğinde ise 1990'lı yılların başında 56 milyon civarında olan ülke nüfusun günümüzde 80 milyon kişiye yaklaştığı görülmektedir. Sığır eti üretimi giderek artan talebe uyum sağlamak durumundadir.

Türkiye'de hayvansal gıdaların kişi başı tüketim miktarı gelişmiş ülkelerin oldukça gerisindedir (Gürer ve Ören, 2013). Kırmızı et tüketimi açısından yüksek, orta, düşük tüketim sınıfı olmak üzere üç gruba ayrılan ülkeler arasında Türkiye düşük tüketim sinifina girmektedir (Lorcu ve Bolat, 2012; Anonim, 2017b). Belirtilen yıllar arasındaki sığır eti tüketim verilerinin tamamına ulaşılamamıştır. 2015 yılında Türkiye'de kişi başına yıllık kırmızı et tüketimi 16 kg olarak belirlenmiştir. Bunun 1.7 kg'ı küçükbaş hayvan etine aittir (Anonim, 2016). Düşük olan tüketim düzeyinde üretim miktarı yeterli gibi görünse de; hem tüketim hem de daha yüksek olması istenen tüketime göre üretim miktarı yetersiz düzeyde kalmaktadır. Tüketimin düşük olmasının en önemli sebepleri gelir dağılımı adaletsizliği ve kırmızı et fiyatlarının yüksek olmasıdır. Tüketiciler düşük gelirleri nedeni ile yüksek fiyatlı sığır etine ekonomik olarak erişmekte güçlük çekmektedir. 
Çizelge 1. 1992-2016 yıllarına ait Türkiye'deki sığır varlığı, sığır eti üretim miktarı ve ülke nüfusuna ilişkin veriler

\begin{tabular}{cccc}
\hline Yıllar & Sığır Varlı̆̆ı (Baş) & Siğır Eti Üretim Miktarı (Ton) & Ülke nüfusu (Kişi) \\
\hline 1992 & 11.973 .000 & 300.652 & $56.473 .035^{*}$ \\
\hline 1993 & 11.951 .000 & 296.066 & - \\
\hline 1994 & 11.910 .000 & 316.654 & - \\
\hline 1995 & 11.901 .000 & 292.447 & - \\
\hline 1996 & 11.789 .000 & 301.828 & - \\
\hline 1997 & 11.886 .000 & 379.541 & - \\
\hline 1998 & 11.185 .000 & 359.273 & 64.729 .501 \\
\hline 1999 & 11.031 .000 & 349.681 & 65.603 .160 \\
\hline 2000 & 11.054 .000 & 354.636 & 66.401 .851 \\
\hline 2001 & 10.761 .000 & 331.589 & 67.187 .251 \\
\hline 2002 & 10.548 .000 & 327.629 & 68.010 .215 \\
\hline 2003 & 9.804 .000 & 290.455 & 68.860 .539 \\
\hline 2004 & 9.788 .102 & 364.999 & 69.729 .967 \\
\hline 2005 & 10.069 .346 & 321.681 & 70.586 .256 \\
\hline 2006 & 10.526 .440 & 340.705 & 71.517 .100 \\
\hline 2007 & 10.871 .364 & 431.963 & 72.561 .312 \\
\hline 2008 & 11.036 .753 & 370.619 & 73.722 .988 \\
\hline 2009 & 10.859 .942 & 325.286 & 74.724 .269 \\
\hline 2010 & 10.723 .958 & 618.584 & 75.627 .384 \\
\hline 2011 & 11.369 .800 & 644.906 & 76.667 .864 \\
\hline 2012 & 13.914 .912 & 799.344 & 77.765 .904 \\
\hline 2013 & 14.415 .257 & 869.292 & 78.741 .053 \\
\hline 2014 & 14.223 .109 & 881.999 & 79.814 .871 \\
\hline 2015 & 13.994 .071 & 1.014 .925 & \\
\hline 2016 & 14.080 .155 & 1.300 .000 & \\
\hline$* 1990$ y1lna ait nüfus sayım sonucudur. Kaynak: Anonim $2017 \mathrm{a}$. & \\
\hline
\end{tabular}

Türkiye'de 2009 yılında yoksulluk oranı (gida ve gıda dışı) \% 18 olarak belirlenmiştir (Anonim, 2017a). 20072011 yılları itibariyle nüfusun yaklaşık olarak üçte ikisi gibi büyük bir oranının iki günde bir et, tavuk ya da balık içeren yemek yeme durumunun olmadığı tespit edilmiştir (Niyaz ve İnan, 2016; Anonim, 2017a)

\section{Türkiye'de Sığır Eti Dış Ticareti}

1992-2016 yılları arasındaki sığır ihracat ve ithalat miktarına (baş) ve sığır eti ihracat ve ithalat miktarlarına ait veriler Cizelge 2'de verilmiştir. Buna göre sığır eti üretiminde ülke içi ihtiyacını ancak karşılayabilen Türkiye'nin sığır eti ihracatı buna paralel olarak oldukça düşüktür. 1997 yılında canlı hayvan ithalatı durdurulmuş ve kasaplık sığır ithalatı yapılamamıştır (Anonim, 2000). Sığır eti ithalatına ilişkin gümrük vergilerinin 2010 yılında \% 220'lerden \% 20'lere kadar düşürülmesi sonucunda ise bu yıldan sonra özellikle 2011 ve 2015 ylllarında ithalat oldukça artmıştır (Anonim, 2010a).

\section{Türkiye'de Sığır Eti ve Yem Fiyatları}

2005-2016 yılları arasındaki sığır eti üretici ve tüketici fiyatları ile besi ve süt yemi fiyatları Çizelge 3'te verilmiştir. 1992-2004 yılları arasında yeterli veriye ulaşılamamıştır. İlk olarak sığır etine ait üretici ve tüketici fiyatları incelendiğinde her ikisinde de yıllar itibari ile artış gözlenmektedir. 2007 yılındaki tüketici fiyatı 2015 yılına gelindiğinde 2,5 kattan fazla artış göstermiştir. Aynı yıllar arasındaki üretici fiyatı artışı ise yalnızca 1,5 kat civarındadır. Buna göre tüketici fiyatlarının yükselmesinde aracı ve perakendeci kurumların rolü büyüktür. Tüketici fiyatı artarken üretici fiyatının aynı oranda artmaması üretimin sürdürülebilirliğini tehdit etmektedir. Yine ithalatın 2010 yılında serbest birakılmasından bir yıl sonra 2011 yılında tüketici fiyatı $0,80 \mathrm{kurus} / \mathrm{kg}, 2012$ yılında ise 2010 yılına göre sadece $0,30 \mathrm{kuruş} / \mathrm{kg}$ gibi çok yetersiz bir düşüş göstermiştir. 2016 yılına gelindiğinde ise 2010 yılındaki $\mathrm{kg}$ fiyatına tüketici düzeyinde 14,2 TL zam geldiği görülmektedir. Artan sığır eti fiyatlarının önüne geçilmesinde ithalat kısa vadede önemli bir gerileme yaratmazken, uzun vadede ise tamamen tüketici ve üretici aleyhine işlemiştir.

Sığır eti fiyatları artışında diğer önemli unsurlardan biri ise girdi maliyetlerinin yüksek olmasıdır. Hayvansal üretimde en önemli masraf unsurlarından biri olan yem fiyatları kırmızı et arzını önemli ölçüde etkilemektedir. Hayvansal üretimde yem masrafları, işletme masraflarının \% 55-65 gibi büyük bir kısmını oluşturmaktadır (Turhan ve ark., 2010). 
Çizelge 2. 1992-2016 yılları arasındaki sığır ihracat ve ithalatına ilişkin veriler

\begin{tabular}{|c|c|c|c|c|}
\hline Yillar & $\begin{array}{l}\text { Siğır Eti İhracat } \\
\text { Miktarı (Ton) }\end{array}$ & $\begin{array}{l}\text { Sığır İhracatı } \\
\text { (Baş) }\end{array}$ & $\begin{array}{l}\text { Sığır Eti ithalat Miktarı } \\
\text { (Ton) }\end{array}$ & $\begin{array}{c}\text { Sığır İthalatı } \\
(\mathrm{Baş})\end{array}$ \\
\hline 1992 & 301 & 0 & 29.583 & 181.988 \\
\hline 1993 & 623 & 0 & 31.861 & 167.390 \\
\hline 1994 & 7 & 0 & 9.123 & 22.057 \\
\hline 1995 & 24 & 0 & 41.493 & 423.726 \\
\hline 1996 & 39 & 0 & 16.575 & 176.634 \\
\hline 1997 & 33 & 0 & 548 & 29 \\
\hline 1998 & 12 & 0 & 0 & 0 \\
\hline 1999 & 18 & 0 & 1 & 271 \\
\hline 2000 & 21 & 3 & 5 & 1.449 \\
\hline 2001 & 9 & 18.041 & 0 & 290 \\
\hline 2002 & 0 & 279 & 0 & 0 \\
\hline 2003 & 0 & 0 & 0 & 2.128 \\
\hline 2004 & 4 & 0 & 0 & 0 \\
\hline 2005 & 0 & 0 & 0 & 1.922 \\
\hline 2006 & 7 & 0 & 0 & 483 \\
\hline 2007 & 184 & 0 & 0 & 3.854 \\
\hline 2008 & 266 & 0 & 0 & 5.393 \\
\hline 2009 & 62 & 0 & 0 & 4.010 \\
\hline 2010 & 66 & 7 & 50.568 & 140.045 \\
\hline 2011 & 59 & 0 & 110.731 & 470.796 \\
\hline 2012 & 80 & 84 & 25.437 & 471.571 \\
\hline 2013 & 62 & 379 & 6.141 & 193.907 \\
\hline 2014 & 40 & - & 640 & - \\
\hline 2015 & 40 & - & 17.574 & - \\
\hline 2016 & $45^{*}$ & - & $3.218^{*}$ & - \\
\hline
\end{tabular}

*9 aylık verileri kapsamaktadır.

Kaynak: Anonim, 2017b.

Çizelge 3. 2005-2016 yılları arasındaki sığır eti tüketici ve üretici fiyatları ile besi ve süt yemi fiyatları (TL/kg)

\begin{tabular}{ccccc} 
Yıllar & $\begin{array}{c}\text { Siğır Eti Tüketici } \\
\text { Fiyatı (TL/kg) }\end{array}$ & $\begin{array}{c}\text { Siğır Eti Üretici } \\
\text { Fiyatı }(\mathrm{TL} / \mathrm{kg})\end{array}$ & $\begin{array}{c}\text { Besi Yemi Fiyatları } \\
(\mathrm{TL} / \mathrm{kg})\end{array}$ & $\begin{array}{c}\text { Süt Yemi Fiyatları } \\
(\mathrm{TL} / \mathrm{kg})\end{array}$ \\
\hline 2005 & - & 9,6 & 0,300 & 0,314 \\
\hline 2006 & - & 10,3 & 0,313 & 0,326 \\
\hline 2007 & 13,8 & 11,2 & 0,400 & 0,412 \\
\hline 2008 & 15,3 & 11,7 & 0,478 & 0,497 \\
\hline 2009 & 17,4 & 13,4 & 0,426 & 0,445 \\
\hline 2010 & 24,1 & 18,4 & 0,479 & 0,490 \\
\hline 2011 & 23,3 & 18,5 & 0,616 & 0,635 \\
\hline 2012 & 23,8 & 17,5 & 0,684 & 0,710 \\
\hline 2013 & 24,5 & 15,6 & 0,708 & 0,744 \\
\hline 2014 & 28,4 & 15,8 & 0,758 & 0,782 \\
\hline 2015 & 35,8 & 17,1 & 0,748 & 0,791 \\
\hline 2016 & 38,3 & - & 0,791 & \\
\hline
\end{tabular}

Kaynak: Anonim, 2016.

Girdilerin çoğunlukla ithal menşeili olması ve TL'nin döviz karşısında giderek değer kaybetmesi sonucu maliyet enflasyonu yükselmektedir. Maliyetler artarken üretici fiyatının aynı oranda artmaması, üretimin sürdürülebilirliğini tehdit etmektedir. Besi ve süt yemi fiyatları 2005 yılından 2016 yılına gelindiğinde yaklaşık 2.5 kat artış göstermiştir. Yine bu artış miktarı da üretici fiyatında meydana gelen 
artıştan oldukça fazladır. Büyümekte olan bir sığırda $1 \mathrm{~kg}$ canlı ağırlık artışı sağlamak için 6-7 kg yem, yaşlı bir sığırda ise $12-14 \mathrm{~kg}$ yem verilmesi gerekmektedir (Anonim, 2010b). 2015 yllinda $1 \mathrm{~kg}$ besi yemi ortalama 0,748 TL/kg'dır (Anonim, 2016). 1 kg canlı ağırlık artışı için ortalama $13 \mathrm{~kg}$ yem yiyen bir besi hayvanının sadece yem masrafı $9.724 \mathrm{TL} / \mathrm{kg}$ 'dır. $1 \mathrm{~kg}$ etin satış fiyatı ise 17,1 TL'dir. Üreticinin diğer masraflarını karşılaması ve geçimini sağlaması için eline kalan tutar 7,37 TL/kg'dır. Bu koşullar altında hayvansal ürünlerin üretiminin ekonomik sürdürülebilirliği de tehdit altında görünmektedir.

Süt fiyatları da kırmızı etin arz miktarı üzerinde etkilidir. Süt fiyatları, masrafları karşılayamayacak düzeyde olduğu zaman üreticiler anaç hayvanlarını kesime göndermektedir. 2016 yılında $1 \mathrm{~kg}$ süt fiyatı 1.15 TL'dir (Anonim, 2017c). Çiğ/süt yem paritesinin 1 değerinin altına düşmesi, $1 \mathrm{lt}$ sütten elde edilen gelirin $1 \mathrm{~kg}$ yem masrafını karşlamadığ gelmektedir. Ekonomik anlamda sürdürülebilir üretim için bu paritenin 1,5 ve üzerinde değer alması beklenmektedir. 2016 yılının Ocak ayında 1.513 olan çiğ süt/yem paritesi Aralık ayında 1.237'ye gerilemiştir (Anonim, 2017d).

Türkiye'de Son 25 Ylllık Sığır Eti Üretim ve Dış Ticaretine Yönelik Politikaların ve Uygulamalarının Incelenmesi

Türkiye'de hayvansal üretim ile ilgili tarım politikalarının amacı, gelişmiş ülkelerde olduğu gibi sığır yetiştiriciliğini yönlendirmek, sığır ve dana eti piyasasında istikrarı sağlamak, uluslararası pazarlarda rekabet etmek, bu piyasaların geleceğine ilişkin tahminlerde bulunmak ve et üreticilerine yeterli geliri sağlamak olmalıdır (Aksoy, 2007). Fakat bu çerçevede, Türkiye'de hayvansal üretim alanına yönelik yeterli ve tutarlı tarımsal politikalar mevcut değildir.

Geçmişte Türkiye bölgenin en büyük hayvan üreticisi ve ihracatçısı konumunda iken ithalatçı bir ülke konumuna gerilemiştir (Narin, 2011). Bunda bugüne kadar olan ülkedeki ekonomik değişimlerin ve belirlenen tarım politikalarının etkisi büyüktür. Türkiye'de hayvansal ürünlerin üretim ve tüketimine yönelik sorunlar uzun yıllardır mevcuttur (Lorcu ve Bolat, 2012). Ancak 24 Ocak 1980 döneminde alınan ekonomik istikrar tedbirleri sonrasinda et ve hayvansal ürünlerin destekleme kapsamından çıkarılması ile daha da derinleşmiştir. Serbest piyasa mekanizmasına birakılmayacak kadar stratejik olan tarım sektörü ve buna paralel olarak hayvancılık bu süreçten olumsuz etkilenmiştir. Desteklerin kaldırılması ve Kamu İktisadi Teşebbüsleri'nin tarımdaki rolünün azaltılması girdi maliyetlerinin, ürün fiyatlarının ve dışa bağımlılığın artmasına neden olmuştur (Ertuğrul, 2000; Köse, 2002).
1980 kararları ile başlayan liberalleşme etkisi 1990’lı yıllarda da devam etmiştir (Soyak, 2003). Bu durum da beraberinde bazıları kar dahi eden Kamu İktisadi Teşebbüslerinin özelleştirilmesi ve devlet kontrolünden çıkarılmasına neden olmuştur (Narin, 2011).

1980'li yıllarda kapsamı daraltılan tarımsal desteklerin ürün kapsamı 1990'lı yılların başında yeniden genişletilmiştir. Bu bağlamda hayvancılık alaninda yem, damızlık hayvan, suni tohumlama konularında kesintili olarak desteklemeler uygulanmıştır. Ürün bazında uygulanan süt ve et teşvik primi gibi sübvansiyonlar yine kesintili olarak verilmiştir. Kredi sübvansiyonu ise ağırlıklı olarak girdi sağlanmasında kullandırılmış ve piyasadan daha uygun koşullarda girdi sağlanmıştır (Abay ve ark., 2005; Narin, 2011).

1992 yılında hayvansal üretim açısından üç saç ayağı olarak bilinen Et Balık Kurumu (EBK), Süt Endüstrisi Kurumu (SEK) ve Yem Sanayi Türk Anonim Şirketi (YEMSAN) Bakanlar Kurulu kararı ile özelleştirme kapsamına alınmıştır. İlk olarak aynı yıl SEK özelleştirilmiştir (Şenol ve Yörür, 2006).

1994 yılında ülke çapında etkili bir ekonomik kriz ile karşı karşıya kalınmıştır. Bu kriz kamu borçlarında açık verilmesine neden olmuştur. Bu krizin etkilerini azaltmak amacı ile 5 Nisan 1994'te 94 kararları olarak bilinen bazı tedbirler açıklanmıştır. Yaşanan kriz ve bunun sonucunda alınan kararlardan ülke ekonomisindeki tüm sektörler gibi tarım sektörü ve Kamu İktisadi Teşebbüsleri de payını almıştır (Köse, 2002).

1995 yılına gelindiğinde, 1992 yılında özelleştirilen SEK'in ardından hayvansal üretim ve tüketim dengesi üzerinde oldukça etkili olan EBK ve YEMSAN'da kamuya vergi yükü yarattıkları gerekçesi ile özelleştirilmiştir (Şenol ve Yörür, 2006). Böylelikle sütten sonra et ve yem sanayi de devlet kontrolünden çıkıp tamamen özel sektörün insafına bırakılmıştır. Hayvancılık alanında çok önemli rolü olan bu kurumların özelleştirilmesi ile üreticiler ürününü değerinin çok altında satmak ya da hayvanlarını kesime göndermek zorunda kalmışlardır (Narin, 2011). Türkiye'de canlı hayvan ve et piyasasının serbest piyasa koşullarında değerlendirilmesi mümkün değildir. Kırsal kesimdeki hayvan yetiştiricileri genellikle küçük ölçekli (Anonim, 2006) ve pazarlık gücü zayıf işletmelerdir. Bu kapsamda üreticileri alıcılar karşısında zayıf bırakan oligopol bir piyasadan bahsetmek mümkündür (Günlü, 2011). Aynı yıl Gümrük Birliği kararı da kabul edilmiştir (Anonim, 2017e).

1996 yılında Gümrük Birliği kararı uygulamaya girmiştir. Türkiye, AB'den 1998 yılında 18.000 ton parça et, 3.000 ton kesim amaçlı hayvan ithal edeceğini taahhüt etmiştir (Karakuş, 2011). 
1998 yılına gelindiğinde Türkiye et ithalatı taahhüdünü BSE hastalığı riskini öne sürerek gerçekleştirmemiştir. Daha sonra 11. fasılda Türkiye'nin Avrupa Birliği (AB)'e uyguladığı ithalat yasağının kaldırılması istenecektir (Anonim, 2004). Aynı yıl çıkarılan mera kanunu kapsamında meraların korunması ve geliştirilmesi amaçlanmıştır (Anonim, 1998).

2001 yılında Türkiye'de ekonomik bir kriz yaşanmıştır (Ercan, 2001). Kriz dönemlerinde genellikle tarım sektörü üzerindeki kamu desteğini azaltacak önlemler alınmıştır. Fakat büyümeye katkı sağlaması açısından tarım sektörünün Gayri Safi Yurt İçi Hasıla (GSYIH) içindeki payının artması gerekmektedir.

2005 yılında 1995 yılında özelleştirilen EBK özelleştirme kapsamından çıkarılmış ve Et ve Süt Kurumu olarak görevine devam etmiştir (Anonim, 2017f). Fakat bu kurum eski etkinliğini yakalayamamıştır. EBK, 1975 yılında Türkiye'nin et kesiminin \% 35'ini gerçekleştirirken Et ve Süt Kurumu'nda 2000'li yıllarda bu oran yok denecek kadar azdır. Bu kurumun yerini özel sektörde kartel oluşturan firmalar almıştır (Özkaya, 2017).

2008 yılında dünya ile paralel olarak Türkiye'de tekrar bir ekonomik kriz yaşamıştır. Bu krizin çıkış noktası Amerika Birleşik Devletleri (ABD)'nde bankacılık sistemindeki konut kredilerinin geri ödemelerinde yaşanan sorunlar olarak belirtilmiştir (Yılmaz, 2013). Tarım sektörü açısından, 2008 yılında dünya genelinde artan girdi fiyatları (petrol, yem vs.) maliyetleri artırıcı yönde bir etki göstermiştir. Buna bağlı olarak tarımsal ürünlerde genel fiyat seviyesi artmıştır (Anonim, 2008).

2008-2009 yılları arasında yağsız süt tozunun buzağı maması adı altında ithalatına izin verilmiştir. $\mathrm{Bu}$ durum çok sayıda anaç süt ineğinin kesimine ve yavru kaybına neden olmuştur. Niyaz (2015) tarafindan yapılan çalışmaya göre süt üreticilerinin $\% 86$ 'sı süt tozu ithalatından olumsuz etkilendiklerini belirtmiştir (Niyaz, 2015). 2011 yılında süt tozu ithalatı \% 75’lere varan oranlarda kısıtlanmıştır (Anonim, 2014).

Türkiye'de 2010 yılına kadar hayvancılık alanında fiyat politikası genellikle ülke içi fiyatların desteklenmesi yönünde olmuştur. İthalat kısitlamaları, gümrük tarifeleri ve bazı ürünlerde doğrudan piyasa müdahaleleri uygulanan diğer politika araçlarıdır. Üretim miktarını, verimi ve üretici gelirini arttırmak amacı ile girdi ve kredi sübvansiyonları sağlanmıştır. 2010 yılına gelindiğine ise kırmızı etteki ithalat yasağı kaldırılmıştır. Gümrük vergileri \% 225'e varan oranlardan \% 20'lere kadar çekilerek ithalatın önü açılmıştır (Anonim, 2010a). Özel sektöre ithalat yapma imkanı tanınmiştır.

2013 yılında Ulusal Süt Konseyi kurulmuştur. Konseyin ana amacı sektörün sorunlarını tespit etmek ve buna yönelik çözüm önerileri geliştirmek olarak belirlenmiştir (Anonim, 2013b).

2015 yılında 1998 yılında çıkarılan mera kanunun ilgili maddelerinde değişiklik yapan bir yönetmelik yayınlanarak meraların imara açılmasının önünü açmıştır (Anonim, 2015).

Planlı dönem itibari ile 2001-2018 yıllarını kapsayan son üç Kalkınma Planında öne çıkan hayvancılık ile ilgili gelişmeler ise şöyledir;

8. Kalkınma Planı'nda (2001-2005) hayvansal üretimde verimin düşük kaldığı ve hayvansal ürün üretiminin geliştirilerek toplumun hayvansal ürün ihtiyacının karşılanması gerektiği, hayvan ıslahı, mera ıslahı alanlarında gelişmeler hedeflendiği belirtilmiştir (Anonim, 2000).

9. Kalkınma Planı'nda (2007-2012) hayvansal üretimde verim ortalamasının düşük ve yem bitkileri üretiminin yetersiz olduğundan bahsedilmiştir (Anonim, 2006). Bu plan döneminde hayvansal üretim ve verim artışında sınırlı bir ilerleme kaydedildiğinden bahsedilmiştir. Hayvansal ürünlerde gida güvenliği oldukça önemlidir (Tosun ve Demirbaş, 2012). 9. Planlı dönemde de gıda güvenliği sorunların olduğuna değinilmiştir. Sınırlarda yasal olmayan hayvan hareketlerinin önlenmesi hedeflenmiştir.

10. Kalkınma Planı'nda kamu kesiminde ve özel sektörde damızlı hayvan yatırımlarının artması sonucunda hayvansal üretimde birim hayvandan elde edilen verimde artış sağlandığı belirtilmiştir. Bunun yanı sıra “Türkiye'de hayvancılık işsletmeleri genelde küçük ölçekli olup yem bitkileri üretimi ile çayrr ve meraların korunma ve 1slahi yetersiz, suni tohumlama sayısı uluslararası ortalamaların altında ve hayvan hareketleri ile hayvan sağglı̆̆na yönelik önlemler yeterlilikten uzak bir durumdadır. Bu bağlamda, Plan döneminde hayvancılık desteklemeleri miktar ve çeşit olarak artırılmıs ve bölgesel projeler uygulamaya $\mathbf{k o}^{-}$ nulmuş, bu destekler son yıllarda et ve süt üretiminde artış getirmistir. Diğer taraftan, aynı dönem içerisinde et üretiminde arz açı̆̆ doğuran gelişmeler ve tüketim artışı et fiyatlarında dalgalanmalara neden olmus ve bu kapsamda 2010 yllnda basslatılan kasaplık canlı hayvan ve et ithalatı azalarak da olsa devam etmiștir." denmiştir (Anonim, 2013c). Fakat 2005-2016 yilları arasındaki sığır eti tüketici fiyatları incelendiğinde yapılan ithalatın uzun vadede fiyatları arttırdığ belirlenmiştir.

\section{SONUÇ ve ÖNERİLER}

Türkiye'de hayvancılık ile ilgili politikalar ve buna bağlı olarak hayvansal ürünlerin üretimi ve dış ticaret miktarı geçmişten günümüze önemli değişimler göstermiştir. Mevcut durum itibari ile sektörde girdi ve ürün piyasalarında dışa bağımlı bir yapı eğilimi gözlenmektedir. 2010 yılında yapılan ithalatın uzun vadede tüketici fiyatlarında düşüşün aksine fiyat 
düzeyinde artışa sebep olduğu görülmektedir. Özellikle son dönemde sığır eti üretim ve dış ticareti ile ilgili belirlenen politikalar hem üretici hem de tüketiciyi memnun etmemektedir.

Türkiye, bitkisel ve hayvansal üretim açısından çok önemli bir potansiyele sahiptir. Türkiye'nin coğrafi ve stratejik konumunu doğru değerlendirecek uzun vadeli, kalıcı üretim ve dış ticaret politikalarının belirlenmesi ayrıca bu politikaların doğru uygulanması gerekmektedir. Öncelikle yerli girdi ve ürün üretimi desteklenmelidir. Sığır eti yetiştiricilerinin en büyük masraf unsurlarından biri yemdir. Yem maddelerinin genellikle ithal menşeili olması döviz kurlarındaki artışların üretimi olumsuz etkilemesine neden olmaktadır. Yerli yem maddesi üretimi ve bu alanda yapılacak tesis yatırımları devlet tarafindan (vergi muafiyeti vs.) desteklenmelidir. Meraların imara açılmasının önüne geçecek yasal düzenlemeler gerekmektedir. Meralar ve otlakların güçlendirilmesi hayvancılık açısından çok önemlidir.

Et ve Süt Kurumu'nun piyasa üzerinde etkisini arttıracak uygulamalar benimsenmelidir. Kurumun et ve süt işleme kapasitesini ve piyasa hakimiyetini arttırmak yolu ile hem üreticiyi hem de tüketiciyi koruması beklenmektedir.

Türkiye'de çok sayıda tarımsal kooperatif ve birlik olmasina rağmen örgütlenme bilinci düşüktür. Buna bağlı olarak etkin ve verimli çalışan tarımsal örgütler sınırlı sayıdadır. Et ve süt üretiminde dikey ve yatay entegrasyon sağlayacak ve etkin çalışacak kooperatiflerin oluşturulması gerekmektedir. Türkiye'de hayvansal üretimin genel yapısı itibari ile üreticilerin büyük bir çoğunluğu küçük ölçekte işletmelere sahiptir. Üreticilerin, büyük firmalar ile rekabet etme şansları ancak kooperatifleşme ile mümkün olacaktır. Kooperatifleşme üreticilere kendi ürünlerinin fiyatlarını belirleme şansı tanırken, girdi maliyetlerinin düşürülmesi ve ürünlerinin katma değer yaratılarak değerlendirilmesine olanak sağlayacaktır.

Türkiye'de kırmızı et tüketim miktarı oldukça düşüktür. Bunun en önemli sebepleri ise gelir dağılımı adaletsizliği ve kırmızı et fiyatlarının yüksek olmasıdır. Hayvansal üretim alanında doğru politikaların belirlenmesi ve uygulanması; başarılı ve etkili bir şekilde kooperatifleşme, sektörün özel sektörün eline tamamen birakılmaması, yerli üretim ile girdi maliyetlerinin düşürülmesi sağlanır ise hem tüketici fiyatı hem de üreticinin eline geçen gelir optimize edilebilecektir.

\section{KAYNAKLAR}

Abay C, Olhan E, Uysal Y, Yavuz F, Türekul B 2005. Türkiye'de Tarım Politikalarındaki Değişim, Türkiye Ziraat Mühendisliği 6. Teknik Kongresi, 37 Ocak 2005, Ankara, www.zmo.org.tr.
Aksoy A 2007. AB'de Sığır ve Dana Eti Ortak Piyasa Düzeni ve Türkiye Açısından Bir Değerlendirme, Atatürk Üniversitesi Ziraat Fakültesi Dergisi, 38(1):97-103.

Anonim 1998. Resmi Gazete, 25 Şubat 2017, Sayı:23419, Ankara.

Anonim 2000. T.C. Kalkınma Bakanlığı, Sekizinci Beş Yıllık Kalkınma Planı, 2001-2005, Ankara.

Anonim 2004. Avrupa Toplulukları Komisyonu, Türkiye'nin Katılım Yönünde İlerlemesi Hakkında 2004 Yılı Düzenli Raporu, Ankara.

Anonim 2006. T.C. Kalkınma Bakanlığı, Dokuzuncu Beş Yıllık Kalkınma Planı, 2007-2012, Ankara.

Anonim 2008. Tarımsal Ekonomi Araştırma Enstitüsü, Ekonomik Göstergelerle Türkiye'de Tarım 2008, Ankara.

Anonim 2010a. Resmi Gazete, 22 Aralık 2020, Sayı: 27793, Ankara.

Anonim 2010b. Gıda, Tarım ve Hayvancılık Bakanlığı, Sığır Besiciliği, Ankara.

Anonim 2013a. Ankara Ticaret Borsası, www.ankaratb.org.tr (Erişim tarihi: 22.08.2017).

Anonim 2013b. Resmi Gazete, 8 Haziran 2013, Sayl: 28671, Ankara.

Anonim 2013c. T.C. Kalkınma Bakanlığı, Onuncu Beş Yillık Kalkınma Planı, 2014-2018, Ankara.

Anonim 2014. Tarımsal Ekonomi ve Politika Geliştirme Enstitüsü (TEPGE), Süt ve Süt Ürünleri Durum Tahmin Raporu 2014, Yayin no: 233, Ankara.

Anonim 2015. Resmi Gazete, 30 Ekim 2015, Sayı:29517, Ankara.

Anonim 2016. Tarımsal Ekonomi ve Politika Geliştirme Enstitüsü (TEPGE), Kırmızı Et Durum Tahmin Raporu 2016, Yayın no: 279, Ankara.

Anonim 2017a. Türkiye İstatistik Kurumu (TÜİK), www.tuik.gov.tr (Erişim tarihi: 22.08.2017).

Anonim 2017b. Food and Agriculture Organization (FAO), www.fao.org (Erişim tarihi: 20.03.2018).

Anonim 2017c. Ulusal Süt Konseyi, www.ulusalsutkonseyi.org (Erişim tarihi: 21.03.2018)

Anonim 2017d. Türkiye, Süt, Et, Gıda Sanayicileri ve Üreticileri Birliği, www.setbir.org (Erişim tarihi: 22.03.2018).

Anonim 2017e. Türkiye Cumhuriyeti Dışişleri Bakanlığ , www.mfa.gov.tr (Erişim tarihi: 02.05.2018).

Anonim 2017f. Et ve Süt Kurumu, www.esk.gov.tr (Erişim tarihi: 02.05.2018).

Dağdemir V, Birinci A, Atsan T 2003. Türkiye'de Kırmızı Et Pazarlaması, Ankara Üniversitesi, Ziraat Fakültesi, 34(4):361-366.

Ercan U 2001. Krizden Krize Türkiye: 20 Kasım ve 2001 Şubat krizleri, Türkiye Ekonomi Birliği Raporu, No:2001/1.

Ertuğrul E 2000. Et ve Et Ürünleri, Türkiye Kalkınma Bankası Sektörel Araştırmalar Raporu, Ankara. 
Gündüz O, Esengün K, Göktolga ZG 2006. Ailelerin Et Tüketimleri Üzerine Bir Araştırma: Tokat Örneği, Türkiye 7. Tarım Ekonomisi Kongresi, Antalya.

Günlü A 2011. Çiğ Süt Pazarlanmasında Süt Sanayi İşletmelerinde Firma Yoğunlaşma Oranlarının Araştırılması: Burdur İli Örneği, Kafkas Üniversitesi Veteriner Fakültesi Dergisi, 17(1):101106.

Gürer B, Ören N 2013. Türkiye'de Hayvansal Ürünlerde Gıda Güvencesinin Analizi, Çukurova Üniversitesi Fen ve Mühendislik Bilimleri Dergisi, 29(3):124-133.

Karakuş K 2011. Türkiye'nin Canlı Hayvan ve Kırmızı Et İthaline Genel Bakış, Iğdır Üniversitesi Fen Bilimleri Enstitüsü Dergisi, 1(1):75-79.

Köse S 2002. 24 Ocak 1980 ve 5 Nisan 1994 İstikrar Programlarının Karşılaştırılması, Planlama Dergisi, 42:119-128.

Lorcu F, Bolat BA 2012. Türkiye'de Kırmızı İthal Et. Hayvansal Üretim, 53(1):14-20.

Narin M 2011. 1980'li Yillardan Sonra Tarım Politikalarındaki Değişiklikler, Ekonomik Yaklaşım Kongresi: Türkiye'nin Dinamikleri: Politika Arayışları, 22-23 Aralık 2011, Ankara.

Niyaz ÖC 2015. Türkiye'de Süt Sektöründe Gıda Güvencesinin Temel Paydaşlar Açısından Tüm Boyutları ile Değerlendirilmesi: TR22 Güney Marmara Bölgesi Örneği, Namık Kemal
Üniversitesi, Fen Bilimleri Enstitüsü, Tarım Ekonomisi ABD, Doktora Tezi, $264 \mathrm{~s}$.

Niyaz ÖC, İnan Hİ 2016. Türkiye'de Gıda Güvencesinin Mevcut Durumunun Değerlendirilmesi, Adnan Menderes Üniversitesi Ziraat Fakültesi Dergisi, 13(2):1-7.

Özkaya T 2017. Kırmızı Et Neden Ulaşılmaz Oldu?, www.izmirtabip.org.tr (Erişim tarihi: 12.03.2017).

Soyak A 2003. Türkiye'de İktisadi Planlama: DPT'ye İhtiyaç Var mı? , Doğuş Üniversitesi Dergisi, 4(2):167-182.

Şenol P, Yörür N 2006. Küreselleşme Sürecinde Kırsal Alanda Neo-liberal Politikalar ve Bütünsel Mekansal Stratejilerin Gerekliliği, 7. Tarım Ekonomisi Kongresi, ss.930-940.

Tosun D, Demirbaş N 2012. Türkiye'de Kırmızı Et ve Et Ürünleri Sanayiinde Gıda Güvenliği Sorunları ve Öneriler, Uludağ Üniversitesi Ziraat Fakültesi Dergisi, 26(1):93-101.

Turhan Ş, Erdal B, Çetin B 2010. Türkiye'de Kırmızı Ette Fiyat Oluşumu ve Etkileyen Faktörler, Türkiye 9. Tarım Ekonomisi Kongresi. 1:387-395. Urfa/Türkiye.

Yllmaz ML 2013. Küresel Finansal Krizin Altın Spot ve Future Piyasalara Etkisi Üzerine Bir Uygulama: Türkiye Örneği, Yüksek Lisans Tezi, Selçuk Üniversitesi, Sosyal Bilimler Enstitüsü, İktisat Anabilim Dalı, İktisat Bilim Dalı, Konya. 